\title{
Exploring the Integration of Disability Awareness into Tertiary Teaching and Learning Activities
}

\author{
Leigh Hale ${ }^{1}$, Jacques van der Meer ${ }^{2}$, Gill Rutherford ${ }^{2}$, Lynne Clay $^{1}$, Jessie Janssen1 \& Denise Powell ${ }^{1}$ \\ ${ }^{1}$ School of Physiotherapy, University of Otago, Dunedin, New Zealand \\ ${ }^{2}$ College of Education, University of Otago, Dunedin, New Zealand \\ Correspondence: Leigh Hale, School of Physiotherapy, University of Otago, Dunedin, New Zealand. E-mail: \\ leigh.hale@otago.ac.nz
}

Received: October 10, 2012

Accepted: November 15, 2012

Online Published: January 16, 2013

doi:10.5539/jel.v2n1p147

URL: http://dx.doi.org/10.5539/jel.v2n1p147

\begin{abstract}
A desire to have every student attending our University be aware of, and reflect on, disability in their studies and future careers, initiated our project to explore how to enhance disability awareness within all our University's papers.In this project we systematically reviewed pertinent literature and ran an action research workshop for staff. Strategies to enhance disability awareness identified in the literature and workshop were presented and verified at an interactive conference presentation. Embedding disability awareness into curricula is challenging; staff considered themselves powerless to bring about change in their departments, but thought that one way to do so would be by modelling inclusive behaviour and by introducing subtle inclusive practices into papers taught. The identified strategies may be of use to others contemplating similar curricular modifications.
\end{abstract}

Keywords: awareness, disability, inclusive behaviour, tertiary education

\section{Introduction}

In 2001, the New Zealand government released its Disability Strategy (Making a World of Difference/Whakanui Oranga); underpinning this strategy was a vision of a fully inclusive society - one in which people with impairment can say they live in "A society that highly values our lives and continually enhances our full participation" (Office for Disability Issues, 2001, p 5). "Kia Örite, Achieving Equity", the New Zealand Code of Practice for an inclusive tertiary education environment for students with impairments, was outlined in 2004 to ensure "success for all New Zealanders through lifelong learning" and, in particular, the focus on "ensuring maximum educational opportunity for all New Zealanders" (New Zealand Ministry of Education Tertiary Education Commission, 2004). In 2010 our University's Vice Chancellor's Advisory Group agreed to the establishment of a working party investigating how the Tertiary Education Committee's "Kia Ōrite" Code of Practice could be implemented (University of Otago, 2010), the results of which are still pending. Whilst many universities now cater admirably for the needs of disabled students (Treby, Hewitt, \& Shah, 2006), and our University has had a Disability Information and Support centre for 20 years, the general awareness of disability across the campus is questionably poor.

The New Zealand Education Act (1989) requires that universities accept the role as being the critic and conscience of society. We would argue that to achieve such a role, to enable all students enrolled at the university to be "global citizens" (Treby, et al., 2006), behoves the university to ensure all students are disability aware; that all students highly value all lives, no matter how diverse, and work towards achieving a fully inclusive society. This desire to have every student at our University, no matter their faculty or level of ability, be disability aware, and to reflect on ensuring a fully inclusive society for all, in their studies and future careers, initiated our project. We asked the question: How can we enhance the content and delivery of disability awareness within papers at our University? This paper reports on a project we completed to answer this question and on the strategies we identified to enhance disability awareness in a tertiary institution.

\section{Method}

Our project comprised two parts: (1) A systematic review of literature pertinent to the enhancement of disability awareness within teaching and learning; and (2) An action research staff workshop aimed at raising awareness of disability issues in teaching and learning activities at our University. This workshop aimed to a/ encourage 
reflection of teaching practice within the disability context, $b$ /make suggestions of how teaching and learning activities could be improved to enhance awareness of disability issues both via content and accessible delivery, and c/to inform the quality development of future such workshops. To verify and expand our findings, we then reported them at an interactive presentation at a Disability Conference and invited feedback from the audience. The project had ethical approval from the University of Otago Human Ethics Committee (11/208).

\subsection{The Literature Review}

We systematically reviewed the literature to answer the question: What processes/systems can be used to raise awareness of disability in teaching staff and students in higher education? We searched nine databases (ERIC, Academic Search Complete, Web of Science, Web of Knowledge, Embase, MEDLINE(R), PsycINFO, PsycEXTRA, Google Scholar) using the key words listed in Table 1. Following review of title and abstracts for relevance to the review, the search yielded 31 articles. On full text review, 18 articles held relevant information on disability awareness training and were included in our review. To be included, articles had to report on raising disability awareness in tertiary institutions. The main reason articles were excluded from our review was their focus on accessibility of people with a disability to education instead of stimulating disability awareness in the curricula.

Table 1. Search terms used in systematic literature review

\begin{tabular}{|c|c|c|c|}
\hline Idea 1 & Idea 2 & Idea 3 & Idea 4 \\
\hline Processes & Awareness & Disability / disabled & Higher education \\
\hline Systems & Attitudes & Physical disability & Tertiary \\
\hline Strategies & Inclusivity & Mental disability & College \\
\hline Workshops & Universal Design/teaching/instruction & Learning disability & Ongoing/further education \\
\hline Interventions & Beliefs & Impairment & Learning institution \\
\hline Training & Understanding & Handicap & Teaching \\
\hline Models of good practice & Accessibility & & Post-secondary \\
\hline In-service training & Issues & & Continuing education \\
\hline Professional & Integration & & Faculty \\
\hline development & Information & & \\
\hline Staff development & Knowledge & & \\
\hline Policies & Perceptions & & \\
\hline Protocols & Recognition & & \\
\hline Disability awareness & Appraisal & & \\
\hline training & Appreciation & & \\
\hline Disability focused & Incorporate & & \\
\hline training & Promote & & \\
\hline \multicolumn{4}{|l|}{$\begin{array}{l}\text { Disability equality } \\
\text { training }\end{array}$} \\
\hline \multirow{2}{*}{\multicolumn{4}{|c|}{$\begin{array}{l}\text { Disability related } \\
\text { workshops }\end{array}$}} \\
\hline & & & \\
\hline \multicolumn{4}{|l|}{ Methods } \\
\hline \multicolumn{4}{|l|}{ Practices } \\
\hline \multicolumn{4}{|l|}{ Approaches } \\
\hline \multicolumn{4}{|l|}{ Actions } \\
\hline \multicolumn{4}{|l|}{ (Online) teaching } \\
\hline \multicolumn{4}{|l|}{ packages } \\
\hline \multicolumn{4}{|l|}{ Course content } \\
\hline \multicolumn{4}{|l|}{ Curriculum development } \\
\hline \multicolumn{4}{|l|}{ Programmes } \\
\hline \multicolumn{4}{|l|}{ Disability studies } \\
\hline \multicolumn{4}{|l|}{ Learning strategies } \\
\hline Classroom techniques & & & \\
\hline
\end{tabular}

\subsection{The Action Research Workshop}

In a half-day action research workshop, contextual presentations and interactive group sessions were aimed at 
encouraging attendees to discuss and reflect on their teaching practice, and to generate suggestions to enhance teaching and learning within the disability context.

The workshop was advertised widely on campus by posters and fliers, in advertisements placed in the University newsletter and by e-mail correspondence. We sent e-mails not only to all staff, but also to Heads of Departments requesting that they encourage staff to attend. The advertising invited all University staff (both academic and general staff) to attend this workshop and it specified that staff attending would be part of an action research project, that their views and opinions would be anonymously analysed and reported at a conference, in a journal publication and in a University grant report. Interested staff were sent the study information sheet and consent form, asked to confirm attendance and to bring the signed consent form to the workshop.

Three lecturers, experienced both in disability issues and pedagogy, conducted the workshop, assisted by two research assistants. The research assistants made observations and field notes of all discussions and collated all material generated by the workshop (such as white board or small group notes) for analysis.

The workshop had three parts: (1) Awareness, (2) Challenges, and (3) Solutions. Each session was facilitated with the use of interactive activities, small group discussions, and DVDs. In the "awareness" session, workshop participants were encouraged to reflect on their own, and their departments, awareness of disability. In the "challenges" session, attendees contemplated on how comfortable they felt about pushing the disability awareness agenda within their individual departments and brainstormed what the constraints to this agenda would be. The last session focussed on "solutions" to these constraints.

\subsection{The Conference Presentation}

As a means of verifying the findings emerging from the workshop and literature review, we gave an interactive platform presentation at the International "Everybody-In" Disability Conference held on our Universitycampus in late 2011. Following a short presentation we invited feedback and further suggestions from the audience, which our research assistant recorded as field notes.

\section{Results}

\subsection{Results of the Literature Review}

Details of the 18 included articles are presented in the appendix (Appendix 1). A number of innovative approaches to raising disability were described or investigated in the reviewed articles. These approaches or interventions included one day workshops (focusing on communication or impairment simulation activities) (Anderson, et al., 2011; Goddard \& Jordan, 1998; Lock, 2003; Moroz, et al., 2010), courses that included clinical placements (Keselyak, et al., 2007; Thompson, et al., 2003), field trips (Livingston, 2000) and classroom work (Matthews, 2009; Wurst \& Wolford, 1994), and the use of YouTube and other similar online video sites (Columna, et al., 2009). More novel initiatives were a national project, involving students, which encouraged the book world to include disabled people in children's books (Matthews, 2010); a course described for social work students which used materials, knowledge and theory developed by disabled people (Meekosha \& Dowse, 2007); suggestions from a first-year literary composition class which described four ways to incorporate disability studies into the curriculum (Patterson, 1994); and a year-long study unit which used students' geography knowledge and skills to address a real-world problem (Treby, et al., 2006). These approaches were used with a variety of students: health professional students (medical, nurses, social work, speech and language, hygiene dental, physiotherapists, occupational therapists, health management) and students of art, design and multimedia, humanities, geography and psychology.

Although a number of innovative methods were described, the effectiveness for many of these interventions was not investigated. In one study that did evaluate their intervention, a significant change in the Attitude Towards Disabled Persons Scale scores $(\mathrm{p}=0.05)$ was reported; course attendants (nurses) had a more positive attitude towards disabled people after completion of a nine month chronic illness course (Thompson, et al., 2003). A meta-analysis of studies investigating simulation of disability activities showed that these activities had little effect on behavioural change (Flower, et al., 2007). Interventions that appeared most effective, based on qualitative feedback, were those which had on-going engagement (Treby, et al., 2006) and real-life/contextualised activities (Matthews, 2010).

\subsection{Results of the Workshop}

Twelve people volunteered to attend the workshop; however only ten staff members ( 1 male, 9 females) participated in the workshop on the day. Attendees (average age: 48 (SD 14) years; age range 25-69 years) came from a range of departments (12 departments representing all four of the University's four faculties (Humanities, Commerce, Sciences, Health) as well as staff from Service and Support departments). Academic staff had on 
average 11 (SD 16) years (range 0 - 45 years) of experience in teaching.

\subsubsection{Identified Challenges}

Workshop attendees felt that little was being done to create awareness for disability in current curricula. The majority of participants perceived that the power to change this was in the hands of the Heads of Departments and the University's Higher Education and Development Centre (HEDC); only a minority considered they could themselves do something to change this. Barriers were seen in 1) attitudes and knowledge, 2) the prescriptive curriculum, and 3) resources (time) and funding constraints.

\subsubsection{Suggested Solutions}

Workshop participants suggested numerous ways to increase disability awareness amongst University staff and students and in the curricular and these suggestions are listed in Table 2. Attendees further recommended that a campaign increasing disability awareness should be targeted at a number of levels, namely a departmental approach, at an individual level with "modelling", networking across campus (and the wider community), building up resources, and inviting guest speakers. Participants held the view that there is generally more acceptance of diversity/inclusion in society today and that this, hopefully, will eventually filter through to universities.

Table 2. Suggested solutions for increasing disability awareness across campus

- $\quad$ Role modelling by "disability aware" staff.

- Personal experience or skills in everyday activities, e.g., at morning tea only using sign language.

- Opportunities to normalise disability, e.g., using images of disability in PowerPoint presentations, instead of those of non-disabled people to illustrate points made.

- Be open to ideas and perceptions of other disability and ethnic cultures.

- Create a disability network, participants meet at lunchtime group to discuss disability issues or discuss journal articles.

- Successful initiatives in departments could be shared with others.

- Working as a department to embed disability issues across a paper.

- Think about diversity and focus on strengths.

- Assessment practices - it would be helpful to the working party to review current assessment practices and make suggestions of new and diverse methods to cater for the differing learning needs and skills of students.

- Prescribe a disability-focussed journal article for students to read and critique on issues.

- Using stories and resources in class that reflect first person experiences.

- Incorporate disability artwork in presentations and posters.

- Assist marketing strategies for disabled groups.

- Develop a resources/inventory of diverse ways disability has been embedded into curricular.

- Invite guest speakers from across the university to present in student papers, thus building relationships with people who have a common interest across departments.

- Think about power base we all work from - who you are as a student/teacher etc. verses those that do not have power. Need to develop "whole"/ critical thinking people because of the "power" they get when they leave university to influence others.

- Students no longer seem to have issues to fight for, because New Zealand students mostly are from "privileged" backgrounds or the fact that students are not challenged? Can we mobilise students on this issue of disability rights?

\subsubsection{Evaluation of the Workshop}

All who attended completed an evaluation questionnaire of the workshop, the main outcome of which was that attendees rated the workshop as highly valuable. When asked what they thought were the best things about the workshop, attendees were enthusiastic about the opportunity to meet others across the University with an interest 
and passion for disability issues, the exposure to a range of expert knowledge about disability including life experience as well as academic expertise, and the group discussions and reflections. By sharing information in this way, with the chance to discuss with and learn from peers in the workplace who share a mutual interest, helped broadening perspectives. One participant said: "my energy to engage in disability issues was restored!"

Suggestions made to improve future such workshops, included: (1) spending more time on finding solutions, (2) making process and outcome expectations clearer, (3) developing a shorter workshop, (4) trying to get wider university involvement, (5) providing more information beforehand about what was to be covered, (6) including an overview from The Disability Office about the services that they currently offer, and (7) providing more specific information to assist students, such as how to provide lecture material in an accessible format.

\subsection{Feedback from the Conference Presentation}

The audience's opinions regarding challenges to raising disability awareness in academic curricular can be broadly categorized as: communication issues, physical and structural barriers, isolation, and teachers' lack of knowledge; verifying our literate review and workshop findings. The audience had additional suggestions for embedding disability into the curriculum. One suggestion made was:

I think when you do something like that (the workshop) you have a great day, but you forget about it. What I did when I was teaching was something that was called "the Deaf world". It was part of a paper. Pupils were taught sign language over three weeks. The people from the Deaf community came and did a workshop. They represented a village and the students had to be the people on the "other side" and had to be understood in sign language. A Deaf person signed a life story to the students. The feedback was that the experience was so strong.

A parent with a disabled child suggested another method to raise awareness. She had participated in inclusive education classes and had told of her experiences of raising a disabled child to students in these classes. She felt she had made an impact on the students and they later said it had been one of their more interesting classes. A final suggestion made was that a change to the Academic Promotions Policy could result in incentivising academics to include disability teaching in their curriculum.

\section{Discussion}

We considered this project successful, in that it generated discussion and identified challenges to embedding disability awareness into the curricular. It also provided solutions, many of which were practical ideas that could be implemented immediately by individuals, and others that would need invested time and commitment to realise. We are however cognisant of the limitations to our work. In spite of both wide and targeted promotion, we only attracted a small sample of people to our workshop, people who already had a passion for raising disability awareness. The University employs about 3,700 full-time staff (academic, research and general staff), yet only 10 people participated. The reasons for this small number may be varied; it was a busy time of year with the final university exams in full swing, potential attendees were deterred by the research involvement of the project, or staff members were not interested. We thus did not gain the opinions and suggestions from a large or diverse group, although our attendees did come from all faculties of the University. Our greatest challenge for future such work lies in attracting larger numbers of staff, as well as staff who presently may not be as interested in the topic as we are.

We initially considered the staff at the University to be the starting point of embedding disability awareness into the curricula, but perhaps, given modern societies increasing acceptance of diversity, we should target young people who generally are more accepting of new ideas, and start the change at the grass-roots level. Perhaps we could elicit advice and assistance from the University's Student Association and that of more philosophically focussed student groups, such as the Students for Environmental Action (SEA), the Queer Support Group, and religious or ethnic/cultural groups. This said; modifying higher education curricular is not easy. The curriculum is fundamental to a higher education institution (Barnett \& Coate, 2005). A case study which explored a curriculum review process at a higher education institution made a number of recommendations for such a process, crucial to which was the need for a collectively shared guiding vision for the curriculum (Hyun\& Oliver, 2011). Supportive administrative leadership was seen to be essential (Hyun\& Oliver, 2011). To embed disability awareness fully into our University curriculum will require a shared vision involving academic and administrative staff, and students; reaching this collaborative point would take concerted effort and time. Probably asimpler strategy to begin with would be to target multiple starting points, both at staff and students levels. Treby et al. (2006) also suggested targeting development at a number of levels, including the personal, output (planning, research skills and presentation and communication) and curriculum level.

Given the importance of University curricular, and the overwhelming task of bringing change to it, may have 
been the reason for the disempowerment staff attending our workshop felt to bring about such change. Staff identified challenges to change as attitudes and knowledge, the prescriptive curriculum, and resources (time) and funding constraints; all issues Hyun and Oliver (2011) highlight as important and requiring attention if change is to be successful. Perhaps another starting strategy would be to focus on small changes. One of the key solutions suggested by workshop attendees was that of "modeling", as individuals we could start modelling what we would like to see in others, and this might be a "small" place to start. In an essay on teaching spirituality and leadership, Rogers (2006) argues that for her students to make sense of life's ethical dilemmas, they required role modelling, to learn from the real-life experiences of their teachers, as one of her students expressed (Rogers, 2006, p. 1):

"It was so important in this course that the instructor participates in this journey with us. I never got the sense that she was sort of leading from afar, or orchestrating some kind of predetermined scheme with us as the spirituality-seeking guinea pigs."

As with spirituality, for many students, with little previous disability (or spiritual) exposure, conceptualising exclusion maybe a difficult, and even a foreign, concept (Livingston, 2000), and seeing fully inclusive behaviours in the everyday actions of their teachers may be a powerful intervention. In addition to modelling inclusive behaviour, individual "modeling" could be done by introducing subtle inclusive practices into papers we teach.

Other "small" strategies that can be incorporated into teaching to increase acceptance of diversity, as suggested by our workshop and conference attendees, include respectfully using pictures of diversity or verbal disability examples to illustrate points made in lectures, using large font size on power point slides, or presenting verbally and in sign. Real-life problems that students have to research and solve, which involve interacting with disabled people (Treby, et al., 2006), may also be useful ways in which to raise awareness. From our literature review, however, we are informed that such strategies should not be short-term, such as a one day workshop, but should be an on-going engagement (Treby, et al., 2006). Furthermore, introducing students using artificial simulation activities appears ineffective and may, in fact, produce the opposite to what was intended. French (1992) considers that participants of such activities tend only to focus on the negative aspects of disability, reinforcing undesirable stereotypes. Participants may trivialise disability, as the simulation activities represent a sudden onset of impairment rather than what it is really like to live with a long-term disability (French, 1992). Real-life and contextualised activities (Matthews, 2010) and reflection and discussion on one's own behaviours towards disabled people, exploring disabled identity, and the oppression of disabled people may encounter and ways in which this oppression can be removed, as suggested by French (1992), may be better strategies to employ.

More ambitious strategies were suggested by our workshop and conference attendees. One suggestion was a review of current assessment practices to make suggestions of new and diverse methods to cater for the differing learning needs and skills of students, a sentiment shared by Hurtado (2009). A second suggestion was that the University's Academic Promotions Policy could be changed to incentivise academics to include disability teaching in their curriculum. Such a policy change had been successfully implemented to drive research (Harland et al., 2010). These "larger" changes would need to be driven from higher academic administration.

Another practical suggestion made was to create a disability network across campus; individuals in this network could meet to discuss disability issues or discuss journal articles. Such a network may be effective in bringing about change as it fulfils the requirements of Wenger's "communities of practice" (Wenger, 1998). Communities of practice, which are epitomised by a group of people who take part in communal learning in an area of shared interest, have been found to drive strategy, problem solve, and foster best practice (Wenger, 1998). Another example of a community of practice was our workshop, which attendees considered valuable; especially appreciated was the opportunity to discuss with and learn from peers in the workplace who share a mutual interest. In the future we would like to improve our workshop programme (based on our participants' suggestions) and run more staff workshops.

\section{Conclusion}

This was a small project which explored, with interested staff, ways in which we can enhance the content and delivery of disability awareness within papers at our University. Whilst our participants considered major curriculum change was beyond their power, they suggested many smaller ways in which change could be instigated. These suggestions were confirmed and expanded by a review of current literature. The identified strategies may be of use to others contemplating similar curricular modifications. We plan to incorporate some of the strategies suggested into one or two existing University courses and evaluate their success in raising disability awareness in students attending the course. 


\section{Acknowledgments}

Funding was provided by the University of Otago Quality Improvement Grant.

The authors acknowledge the assistance of the Higher Education and Development Centre, University of Otago; Donna-Rose McKay, Head of Services, Disability Information and Support, University of Otago; and Dr Brigit Mirfin-Veitch, Director of the Donald Beasley Institute in this project.

\section{References}

Anderson, E. S., Ford, J., \& Thorpe, L. (2011). Learning to listen: Improving students' communication with disabled people. Medical Teacher, 33(1), 44-52. http://dx.doi.org/10.3109/0142159X.2010.498491

Barnett, R., \& Coate, K. (2005). Engaging the curriculum in higher education. The Society for Research in Higher Education. Maidenhead: Open University Press.

Columna, L., Arndt, K., Lieberman, L., \& Yang, S. (2009). Using online videos for disability awareness. Journal of Physical Education, Recreation \& Dance, 80(8), 19-24.

Eddey, G. E., \& Robey, K. L. (2005). Considering the culture of disability in cultural competence education. Academic Medicine, 80(7), 706-712. http://dx.doi.org/10.1097/00001888-200507000-00019

Flower, A., Burns, M. K., \& Bottsford-Miller, N. A. (2007). Meta-analysis of disability simulation research. Remedial and Special Education, 28(2), 72-79. http://dx.doi.org/10.1177/07419325070280020601

French, S. (1992). Simulation Exercises in Disability Awareness Training: A Critique. Disability \& Society, 7(3), 257-266. http://dx.doi.org/10.1080/02674649266780261

Goddard, L., \& Jordan, L. (1998). Changing attitudes about persons with disabilities: Effects of a simulation. The Journal of Neuroscience Nursing, 30(5), 307-313. http://dx.doi.org/10.1097/01376517-199810000-00006

Harland.T., Everett, E., Hale, L., Pickering, N., \& Tidswell, T. (2010). Neoliberalism and the academic as critic and conscience of society. Teaching in Higher Education, 15(1), 85-96. http://dx.doi.org/10.1080/13562510903487917

Hurtado, S. (2009). Assessing higher education's advancement toward a new vision of society. Diversity and Democracy, 12(1), 1-3.

Hyun, E., \& Oliver, S. L. (2011). Comprehensive curriculum reform in higher education: Collaborative engagement of faculty and administrators. Journal of Case Studies in Education, 2, 1-20.

Keselyak, N. T., Simmer-Beck, M., Bray, K. K., \& Gadbury-Amyot, C. C. (2007). Evaluation of an academic service-learning course on special needs patients for dental hygiene students: A qualitative study. Journal of Dental Education, 71(3), 378-392.

Livingston, K. (2000). When Architecture Disables: Teaching Undergraduates to Perceive Ableism in the Built Environment. Teaching Sociology, 28(3), 182-191. http://dx.doi.org/10.2307/1318988

Lock, E. (2003). A Workshop for Medical Students on Deafness and Hearing Impairments. Academic Medicine, 78(12), 1229-1234. http://dx.doi.org/10.1097/00001888-200312000-00006

Matthews, N. (2009). Teaching the "invisible" disabled students in the classroom: disclosure, inclusion and the social model of disability. Teaching in Higher Education, 14(3), 229-239. http://dx.doi.org/10.1080/13562510902898809

Matthews, N. (2010). Anxiety and niceness: Drawing disability studies into the art and design curriculum through a live brief. Discourse, 31(4), 527-541. http://dx.doi.org/10.1080/01596306.2010.504368

Meekosha, H., \& Dowse, L. (2007). Integrating critical disability studies into social work education and practice: An Australian perspective. Practice: Social Work in Action, 19(3), 169-183.

Moroz, A., Gonzalez-Ramos, G., Festinger, T., Langer, K., Zefferino, S., \& Kalet, A. (2010). Immediate and follow-up effects of a brief disability curriculum on disability knowledge and attitudes of PM\&R residents: A comparison group trial. Medical Teacher, 32(8), e360-e364. http://dx.doi.org/10.3109/0142159X.2010.490602

New Zealand Ministry of Education Tertiary Education Commission. (2004). Kia Ōrite; Achieving Equity. New Zealand Code of Practice for an Inclusive Tertiary Education Environment for Students with Impairments. Retrieved from http://www.tec.govt.nz (10th May, 2012)

Office for Disability Issues. (2001). The New Zealand Disability Strategy. Retrieved from 
http://www.odi.govt.nz/documents/publications/nz-disability-strategy.pdf (10th May, 2012)

Patterson, K. A. (1994). Embodied Curriculum: Teaching disability studies in the first year composition classroom. Paper presented at the 45th Conference on College Composition and Communication. Nashville, Tennessee.

Rogers, J. L. (2006). Role-modeling authenticity in higher education. Spirituality in Higher Education Newsletter, 3(1), 1-5.

Statistics New Zealand. (2011). Ethnicity question for 2006 census. Retrieved from http://www.stats.govt.nz/Census/about-2006-census/2006-census-questionnaires.aspx (30th March, 2011)

Thompson, T. L., Emrich, K., \& Moore, G. (2003). The effect of curriculum on the attitudes of nursing students $\begin{array}{llll}\text { toward disability. } & \text { Rehabilitation } & \text { 27-30. }\end{array}$ http://dx.doi.org/10.1002/j.2048-7940.2003.tb01718.x

Treby, E., Hewitt, I., \& Shah, A. (2006). Embedding "disability and access" into the geography curriculum. Teaching in Higher Education, 11(4), 413-425. http://dx.doi.org/10.1080/13562510600874169

University of Otago. (2010). Guidelines for Teaching at Otago. Retrieved from http://www.otago.ac.nz/staff/otago027122.pdf (10th May, 2012)

Wurst, S. A., \& Wolford, K. (1994). Integrating disability awareness into psychology courses: Applications in abnormal psychology and perception. Teaching of Psychology, 21(4), 233-235. http://dx.doi.org/10.1207/s15328023top2104_7

Wenger, E. (1998). Communities of practice: Learning, meaning, and identity. Learning in doing: Social, cognitive, and computational perspectives. New York, NY: Cambridge University Press. 
Appendix 1. Details of identified articles from literature review

\begin{tabular}{|c|c|c|c|c|}
\hline Author/s (year): Country & Type of Paper & Participants & Method & Findings \\
\hline $\begin{array}{l}\text { (Anderson, Ford, \& Thorpe, } \\
\text { 2011): UK }\end{array}$ & $\begin{array}{l}\text { Research report of an } \\
\text { exploratory action } \\
\text { research. }\end{array}$ & $\begin{array}{l}\text { Mid-late stage students from } \\
\text { medicine, midwifery, nursing, } \\
\text { social work and speech } \\
\text { language. }(\mathrm{n}=109) \\
\text { Disability service users } \\
(\mathrm{n}=20) \text {. }\end{array}$ & $\begin{array}{l}\text { Intervention: One day workshop focusing on } \\
\text { communication with service users. Three pilot } \\
\text { workshops used with follow-up focus groups with } \\
\text { students and service providers and questionnaires to } \\
\text { help modify the workshop. }\end{array}$ & $\begin{array}{l}\text { Meeting and hearing service users' experiences, was the best } \\
\text { aspect according to students. Experience of working alongside } \\
\text { other professions useful. Importance of listening carefully was } \\
\text { highlighted. Service users found experience useful though had } \\
\text { difficulty providing student feedback. }\end{array}$ \\
\hline $\begin{array}{l}\text { (Thompson, Emrich, \& } \\
\text { Moore, 2003): USA }\end{array}$ & $\begin{array}{l}\text { Research report of a } \\
\text { case control study. }\end{array}$ & $\begin{array}{l}\text { Final year baccalaureate } \\
\text { nursing students }(n=41)\end{array}$ & $\begin{array}{l}\text { Research question: what are nursing student attitudes } \\
\text { toward disability as they enter senior year and do } \\
\text { these differ following completion of chronic illness } \\
\text { course? Measured using } 30 \text { item Attitude Towards } \\
\text { Disabled Persons Scale (ATDP). } \\
\text { Intervention: } 9 \text { month course, which included clinical } \\
\text { placements, field trips and classroom work. ATDP } \\
\text { taken pre and post course. }\end{array}$ & $\begin{array}{l}\text { Pre and post ATDP scores showed significant positive change in } \\
\text { attitude towards disabled people after completion of chronic } \\
\text { illness course ( } \mathrm{p}=0.053 \text { ). }\end{array}$ \\
\hline $\begin{array}{l}\text { (Goddard \& Jordan, 1998): } \\
\text { USA }\end{array}$ & $\begin{array}{l}\text { Research report of a } \\
\text { case-control study. }\end{array}$ & $\begin{array}{l}\text { Baccalaureate } \quad \text { nursing } \\
\text { students (control } n=54, \\
\text { experimental } n=67)\end{array}$ & $\begin{array}{l}\text { Measure: attitudes towards Disabled People scale } \\
\text { before training, immediate after, } 6 \text { weeks and } 6 \\
\text { months after. } \\
\text { Intervention: participation in one day ( } 8 \text { hour) } \\
\text { Sensitivity Day - a simulation activity in the } \\
\text { community, panel presentations by disabled people or } \\
\text { carers and a debriefing segment in small groups. }\end{array}$ & $\begin{array}{l}\text { No statistical differences found between the groups at each } \\
\text { stage, but a trend for scores to increase from baseline at } 6 \text { weeks } \\
\text { and } 6 \text { months in both groups. }\end{array}$ \\
\hline $\begin{array}{l}\text { (Keselyak, Simmer-Beck, } \\
\text { Bray, \& Gadbury-Amyot, } \\
\text { 2007): USA }\end{array}$ & $\begin{array}{l}\text { Research report of a } \\
\text { qualitative study. }\end{array}$ & $\begin{array}{l}\text { Dental hygiene students } \\
\text { starting final semester }(n=23) \text {. }\end{array}$ & $\begin{array}{l}\text { Method: Written reflections from students and semi } \\
\text { structured interviews } \\
\text { Intervention: A new course modelled on Service } \\
\text { Learning protocols was set up to prepare students to } \\
\text { be competent in assessing the treatment needs of } \\
\text { special needs patients. Students chose a community } \\
\text { organisation to familiarise themselves with and } \\
\text { identify the needs of the target population - } \\
\text { Alzheimer's disease, smoking cessation or eating } \\
\text { disorders. }\end{array}$ & $\begin{array}{l}\text { The structured link between academic coursework and } \\
\text { community service appeared to enhance student learning and } \\
\text { understanding of special needs and complex social issues } \\
\text { relating to these. Students' written reflections showed they } \\
\text { enjoyed the community interactions and had more confidence in } \\
\text { dealing with special needs individuals. Community organisations } \\
\text { enjoyed the intervention and were keen for it to continue each } \\
\text { year. Tutors felt that the extra time needed in organisation and } \\
\text { liaison was worthwhile. }\end{array}$ \\
\hline (Matthews, 2010): UK & $\begin{array}{l}\text { Research report of a } \\
\text { qualitative study. }\end{array}$ & $\begin{array}{l}\text { Staff and students of art, } \\
\text { design and multimedia courses } \\
\text { at } 4 \text { United Kingdom } \\
\text { universities between } 2005 \text { and } \\
\text { 2007. Interviews with } 8 \\
\text { academic staff and } 27 \\
\text { students. }\end{array}$ & $\begin{array}{l}\text { Method: a critical ethnography. Evaluation was by } \\
\text { interview, participant observation, analysis of } \\
\text { reflective logs, creative work, short qualitative } \\
\text { questionnaire. } \\
\text { Intervention: A national project "In the Picture" which } \\
\text { encouraged the book world to include disabled people } \\
\text { in children's books. Students were asked to illustrate, } \\
\text { animate or make multimedia products based on } \\
\text { inclusive children's stories written by local disabled } \\
\text { people or parents of disabled children. They were } \\
\text { provided with critical readings in disability studies } \\
\text { with a focus on the social model of disability, a short } \\
\text { disability awareness training session and given the } \\
\text { opportunity to participate in a range of activities such } \\
\text { as discussing ideas with children writers, receiving } \\
\text { feedback from authors. }\end{array}$ & $\begin{array}{l}\text { Themes to emerge: should non-disabled teachers seek to } \\
\text { incorporate disability issues within curricula. Is the fear of this } \\
\text { based in the medical model with teachers thinking they need to } \\
\text { be experts? Anxieties of staff and students about lacking } \\
\text { expertise in the area of disability. Is there an element of 'making } \\
\text { nice' the topic to avoid confronting any conflict? Intervention } \\
\text { had an effect on students, as most had never contemplated issues } \\
\text { such as equity and inclusiveness. }\end{array}$ \\
\hline (Moroz et al., 2010): USA & $\begin{array}{l}\text { A research report of a } \\
\text { case control study. }\end{array}$ & $\begin{array}{l}\text { Medical students, } \\
\text { (experimental }=11 \times 2 \text { nd year } \\
\text { students; control }=10 \times 3 \mathrm{rd} \& \\
\text { 4th year students). }\end{array}$ & $\begin{array}{l}\text { Evaluation: All participants completed a brief } \\
\text { demographical questionnaire, a } 30 \text { question multi } \\
\text { choice strategies on disability knowledge and a } 24 \\
\text { question Scale of Attitudes toward Disabled Persons } \\
\text { form (SADP). } \\
\text { Intervention: One day training consisting of lectures } \\
\text { and panel presentations by disabled people followed }\end{array}$ & $\begin{array}{l}\text { Immediate follow-up showed statistically significant } \\
\text { improvements in knowledge and attitudes in participants post } \\
\text { training compared to controls. Attitude scores remained } \\
\text { consistent at } 3 \text { months but knowledge scores had returned to } \\
\text { pre-training levels. Participants found the personal stories from } \\
\text { people with disabilities the most beneficial. }\end{array}$ \\
\hline
\end{tabular}




\begin{tabular}{|c|c|c|c|c|}
\hline & & & $\begin{array}{l}\text { by a simulation exercise. Participants completed multi } \\
\text { choice knowledge test after the lectures and panel and } \\
\text { the SADP following the simulation exercise. } \\
\text { Knowledge and SADP where re-administered three } \\
\text { months later also. } \\
\text { Control group: no intervention. }\end{array}$ & \\
\hline $\begin{array}{l}\text { (Treby, et al., 2006): } \\
\text { UK }\end{array}$ & $\begin{array}{l}\text { Research report of a } \\
\text { case study. }\end{array}$ & $\begin{array}{l}\text { 3rd year undergraduate } \\
\text { applied geography students ( } \mathrm{n} \\
=\text { not reported). }\end{array}$ & $\begin{array}{l}\text { Intervention: Year-long unit aimed at using geography } \\
\text { knowledge and skills to address a real-world problem. } \\
\text { Students worked in groups and could choose one of } \\
\text { four issues, one of which was disability and } \\
\text { awareness around the university campus. Groups had } \\
\text { weekly tutorials/workshops with assigned tutor and } \\
\text { email contact/face to face conversations informally as } \\
\text { required. Evaluation was by on-going performance } \\
\text { assessment by tutor over the year, students portfolios } \\
\text { including written reflective logs and an overall } \\
\text { presentation of the project in oral, poster or written } \\
\text { format }\end{array}$ & $\begin{array}{l}\text { Students found topic difficult to conceptualise initially and } \\
\text { required considerable tutor intervention. In their reflective logs } \\
\text { students found the sensitivity of the subject difficult, they } \\
\text { became aware of their own (mis)conceptions around disability, } \\
\text { importance of having a real life issue to show value of } \\
\text { geography skills was important. Staff involved realised that their } \\
\text { views changed towards disability as they worked though student } \\
\text { issues. That translating inclusivity into the curriculum is not easy } \\
\text { and a minority of staff will always fail to see the importance. } \\
\text { Staff used team-teaching so they could get support and to ensure } \\
\text { consistent marking. Staff development was needed to allow staff } \\
\text { to think about disability issues. }\end{array}$ \\
\hline $\begin{array}{l}\text { (Flower, Burns, \& Bottsford } \\
\text { - Miller, 2007): USA }\end{array}$ & $\begin{array}{l}\text { Systematic review } \\
\text { with a meta-analysis. }\end{array}$ & $\begin{array}{l}\text { Reviewed } 41 \quad \begin{array}{c}\text { studies, } \\
\text { identified using } \\
\text { keyword }\end{array} \\
\text { search of } 3 \text { databases - } 10 \\
\text { fulfilled criteria. }\end{array}$ & $\begin{array}{l}\text { Research questions: } \\
\text { a) How effective are disability simulations in } \\
\text { changing attitudes / behaviours of participants? } \\
\text { b) Do any negative effects occur among } \\
\text { participants? }\end{array}$ & $\begin{array}{l}\text { Effect sizes showed a small to negligible effect. Smallest effect } \\
\text { size was in activities that included environmental modifications } \\
\text { such as being in a wheelchair; interaction with disabled people } \\
\text { had the greatest effect size. Do any negative effects occur - not } \\
\text { overall, 6/17 showed negative effects. Mean duration of } \\
\text { simulation exercise was } 2 \text { hours but greatest effect size came } \\
\text { from activities of less than } 30 \text { minutes. }\end{array}$ \\
\hline $\begin{array}{l}\text { (Columna, Arndt, } \\
\text { Lieberman, \& Yang, 2009): } \\
\text { USA }\end{array}$ & Scholarly paper. & - & \multicolumn{2}{|c|}{$\begin{array}{l}\text { Discusses use of YouTube and other similar online video sites to enhance disability awareness training to students. } \\
\text { Recommends a tool for assessing the quality of such videos with respect to how they portray disability and suggests ways } \\
\text { in which teachers can use this approach. }\end{array}$} \\
\hline $\begin{array}{l}\text { (Eddey \& Robey, 2005): } \\
\text { USA }\end{array}$ & Scholarly paper. & - & \multicolumn{2}{|c|}{$\begin{array}{l}\text { Brief description of undergraduate medical student training programme based around learning what the culture of disability } \\
\text { is and how medics can address people from this culture. }\end{array}$} \\
\hline $\begin{array}{l}\text { (French, 1992): } \\
\text { UK }\end{array}$ & Scholarly paper. & - & $\begin{array}{l}\text { Reviews literature on simulation exercises and offers } \\
\text { critical opinion }\end{array}$ & $\begin{array}{l}\text { 1) Little evidence that simulation exercises bring about positive } \\
\text { attitude change towards disability - participants tend to focus on } \\
\text { the negative aspects/feelings only and these exercises may act to } \\
\text { reinforce the negative stereotypes of disability. } \\
\text { 2) Simulation exercises do not simulate the true experience of } \\
\text { disability - they give a false impression and trivialise disability, } \\
\text { they represent sudden onset of impairment rather than living } \\
\text { with long-term disability and participants know that it is } \\
\text { temporary so thoughts/feelings/frustrations will be very } \\
\text { different. The social and psychological difficulties cannot be } \\
\text { simulated. } \\
\text { 3) Simulation exercises individualise disability - they focus on } \\
\text { impairment and ignore the social and cultural factors. } \\
\text { Authors advocated Disability Equality Training based around } \\
\text { exploring how disability is defined in society, participants own } \\
\text { feelings and behaviours towards disabled, disabled identity and } \\
\text { the oppression disabled people may encounter and discussing } \\
\text { ways in which this oppression can be removed through equal } \\
\text { opportunities and empowerment. }\end{array}$ \\
\hline (Matthews, 2009): Australia & $\begin{array}{l}\text { Scholarly paper with } \\
\text { an example of a } \\
\text { classroom exercise. }\end{array}$ & - & $\begin{array}{l}\text { Course students: First year humanities students - } \\
\text { approximately } 150 \text { students in groups of } 25 \text { each with } \\
\text { a different tutor. } \\
\text { Classroom exercise: A discussion of case studies by } \\
\text { students facing challenges to their learning and } \\
\text { support services available. Followed by a review of }\end{array}$ & $\begin{array}{l}\text { How exercise unfolded depended on the tutor - some spent a lot } \\
\text { of time discussing case studies whilst others avoided this as they } \\
\text { felt under-prepared to undertake such "counseling". } 68 \text { reviews } \\
\text { of cultural sites submitted and } 23 \text { referred to inclusivity and } \\
\text { accessibility. Author suggests that "understanding of the social } \\
\text { model of disability may have been promoted by the workshop }\end{array}$ \\
\hline
\end{tabular}




\begin{tabular}{|c|c|c|c|c|}
\hline & & & $\begin{array}{l}\text { cultural sites in the city in terms of how well it bore } \\
\text { out the city slogan of 'the world in one city.' }\end{array}$ & activity". \\
\hline $\begin{array}{l}\text { (Meekosha \& Dowse, } \\
\text { 2007): } \\
\text { Australia }\end{array}$ & $\begin{array}{l}\text { Scholarly paper with } \\
\text { an educational case } \\
\text { study example. }\end{array}$ & - & $\begin{array}{l}\text { Course students: Undergraduate social work students } \\
\text { in their 3rd year of degree. } \\
\text { Course: Report of teaching disability studies as an } \\
\text { elective paper titled "Disability, Policy, Practice and } \\
\text { Politics". Approach used materials, knowledge and } \\
\text { theory developed by disabled people. Students had to } \\
\text { present to the disabled community at a public } \\
\text { conference at the course end. }\end{array}$ & $\begin{array}{l}\text { Case studies were prominent with students encouraged to } \\
\text { reframe the social work intervention in light of their new } \\
\text { learning. }\end{array}$ \\
\hline (Livingston, 2000): USA & $\begin{array}{l}\text { Descriptive paper of } \\
\text { a medical sociology } \\
\text { course on illness and } \\
\text { disability. }\end{array}$ & - & $\begin{array}{l}\text { Course students: medical students, physiotherapy, } \\
\text { occupational therapy, health management, and those } \\
\text { that plan to work with older people or people with } \\
\text { disability. } \\
\text { Course: Describes an exercise (field visit, follow-up } \\
\text { discussion and assignment) in which student groups } \\
\text { analysed a building's architectural barriers to gain an } \\
\text { understanding of how disabled people are excluded } \\
\text { from everyday social interaction. }\end{array}$ & $\begin{array}{l}\text { Common learning themes have appeared over the years: (1) } \\
\text { physical space or lack of, (2) recognition that knowing how } \\
\text { people with disabilities feel is impossible, (3) the link between } \\
\text { social acceptance and the demands of the physical environment, } \\
\text { (4) the meaning of disability is socially constructed }\end{array}$ \\
\hline (Lock, 2003): Canada & $\begin{array}{l}\text { Descriptive paper of } \\
\text { an educational } \\
\text { workshop to improve } \\
\text { healthcare delivery to } \\
\text { deaf and hearing } \\
\text { impaired persons. }\end{array}$ & - & $\begin{array}{l}\text { Course students: Pre-clinical 1st and 2nd year medical } \\
\text { students. } \\
\text { Course: Elective } 3 \text { hour evening workshop consisting } \\
\text { of (1) questionnaire on common misconceptions, (2) } 6 \\
\text { lecture session delivered by deaf or hearing impaired } \\
\text { persons, (3) discussion periods, (4) display table of } \\
\text { aids and written information, 5) case-based sessions } \\
\text { where a deaf/hearing impaired person acted out a } \\
\text { scenario when going to the doctor. }\end{array}$ & $\begin{array}{l}\text { Brief evaluation immediate post workshop suggested students } \\
\text { found it positive and educational as their knowledge around this } \\
\text { topic was minimal, that such workshops should be included in } \\
\text { the curriculum and that the case-based scenarios were the most } \\
\text { valuable. }\end{array}$ \\
\hline $\begin{array}{l}\text { (Wurst \& Wolford, 1994): } \\
\text { USA }\end{array}$ & $\begin{array}{l}\text { Descriptive paper of } \\
\text { a course. }\end{array}$ & - & $\begin{array}{l}\text { Course students: Psychology students } \\
\text { Course: (1) Disability simulation, (2) Classroom } \\
\text { activities, and (3) Speakers (people with disability } \\
\text { talk about experiences and students write up a } \\
\text { reaction paper) used to raise disability awareness in } \\
\text { all students. }\end{array}$ & $\begin{array}{l}\text { Only discussed disability simulation - students only chose visual } \\
\text { or hearing disabilities, quick questionnaire regarding experiences } \\
\text { resulted in generally negative emotional experiences (awkward, } \\
\text { isolated, frustrated and anxious), } 10 \text { open ended questions } \\
\text { revealed empathy toward people with disability, the challenges } \\
\text { they face, how non-disabled people acted, that they would now } \\
\text { be more sensitive and respectful to disabled people and how } \\
\text { difficult it was to participate in class. Concluded that all } 3 \\
\text { techniques have been used successfully. }\end{array}$ \\
\hline $\begin{array}{l}\text { (Patterson, 1994, March): } \\
\text { USA }\end{array}$ & $\begin{array}{l}\text { Conference } \\
\text { presentation. }\end{array}$ & - & \multicolumn{2}{|c|}{$\begin{array}{l}\text { Course students: First year literary composition class } \\
\text { Incorporating disability studies within the curriculum: proposed } 4 \text { ways: (1) balance the negative, stereotypical view of } \\
\text { disability in texts by also using texts that challenge this view, (2) be aware of the biases of the writer, the culture in which } \\
\text { the text was written as well as the readers own biases - use texts from all walks of life to balance the views, (3) organise } \\
\text { part of course around disciplinary approaches such as women's rights, gay rights, disability rights movements and set } \\
\text { assignments for students to examine all sides and argue for one based on own experiences, (4) organise part of course } \\
\text { around ethical dilemmas which can easily incorporate disability issues such as abortion, euthanasia. }\end{array}$} \\
\hline
\end{tabular}

